WAHANA

AKUNTANSI

Jumal Ilmiah
Jurnal Ilmiah, Vol 12 (2) 2017, 122-142

WAHANA AKUNTANSI

http://journal.unj.ac.id/unj/index.php/wahana-akuntansi

\title{
ACCOUNTING FOR THE GLOBAL ECONOMY: IS NATIONAL REGULATION DOOMED TO DISAPPEAR?
}

\author{
Bonifasius Tambunan* \\ Budi Anshari Nasution \\ Halomoan Sihombing \\ Iskandar Muda \\ Universitas Sumatera Utara
}

\section{Keywords:}

regulatory corporation, regulatorycompetition, regulatory contracting-out
Many observers consider accountancy to be the most international of the professions, but differences between countries as to how they regulate accountancy have resulted in barriers which prevent the profession from meeting the changing needs of an increasingly global economy. This paper examines how the European Union has adopted different approaches to overcoming regulatory divergence, and identifies three approaches which have been followed: regulatory cooperation, regulatory competition and regulatory contracting-out. The relative impact of each method is evaluated. Recent developments at worldwide level (under the auspices of the WTO, OECD and IOSCO) are cited to demonstrate that many of the regulatory reforms in Europe are of growing relevance to the United States, and some of the likely changes which will be required are identified. The need for national systems of regulation to evolve in response to the process of globalisation is underlined, and the paper concludes with an assessment of how the accountancy profession might respond to the challenges and opportunities of the new environment.
How to Cite:

Tambunan, Bonifasius, Budi Anshari Nasution, Halomoan Sihombing, dan Iskandar Muda. 2017. Accounting For The Global Economy: Is National Regulation Doomed To Disappear?. Jurnal Wahana Akuntansi, 12(2), 18-38. https://doi.org/10.21009/wahana.12.022 


\section{INTRODUCTION}

It is often said that accountancy is the most international of all the professions. As our clients have evolved to become active throughout the global economy, we have responded. Accountancy firms using the same name are to be found in countries spanning the continents, and the information which accountants provide and attest to is used to support cross-border trade and investment transactions.

But just because a statement is repeated frequently does not mean it is true. The practice of accountancy continues to be governed by regulatory regimes which are predominantly national in character, and insufficient progress has been made to achieve consistency and compatibility between them. This is not necessarily indicative of protectionist intent, but often reflects only how systems of regulation develop in response to national circumstances and political demands. Nonetheless, purely national regimes are not appropriate to the internationalization of markets, since differences in approach give rise to barriers to trade and investment.

My concern is that a profession trapped in outdated, introverted and local structures of regulation has little or no chance of retaining its relevance in a global economy. Change is often unattractive, especially to those with a vested interest in the status quo, but without change even the current systems in place will fade away. The challenge facing us all is to take a new approach to regulation, one which supports the international practice of accountancy rather than impeding it, and one which is responsive to the changing dimension of the public interest in a world where national frontiers become less relevant.

In this paper, I will draw heavily on the experience of the European Union, which has adopted a number of different approaches to overcoming regulatory divergence as it has made progress towards integrating the separate economies of what are now 15 Member States into a single European market.

The European Union is undoubtedly the most extensive, firmly established and successful initiative of regional economic integration-but it is by no means the only oneso many of the lessons learned are of more general application. North America has NAFTA, the Pacific Basin has APEC, South America has MERCOSUR, and the list of similar groupings continues to grow. Equally, efforts to reduce barriers to trade and investment at a worldwide level, primarily through the World Trade Organization (WTO), also draw on EU models in many fields, not least as far as trade in services is concerned.

My focus on Europe, therefore, is intended only to illustrate concepts which are of relevance elsewhere, including the United States as it, too, adapts to the demands of a global economy.

I write against the background of my experience as Secretary General of the Federation des Experts Comptables Europeens (FEE), or Federation of European Accountants. FEE is the representative organisation for the accountancy profession in Europe, grouping 
Bonifasius Tambunan, Budi Anshari Nasution, Halomoan Sihombing, dan Iskandar Muda/ Jurnal Ilmiah Wahana Akuntansi, 12 (2) 2017, 122-142

together the 38 leading institutes in 26 countries, with a combined membership of over 400,000 individuals. Of these, 45 percent are in public practice, providing a wide range of services to clients in both the private and public sectors. The other 55 percent are engagedin a variety of positions in business, government and education. Three percent of the individuals work outside their home country elsewhere in Europe, whilst a much higher nine percent work outside Europe altogether. In part, this is due to the fact that some FEE member bodies make their qualifications available to individuals who are not resident in Europe, but the high proportion of member bodies' members elsewhere in the world helpsto explain why FEE has long taken a close interest in regulatory developments internationally and not just in Europe.

\section{DISCUSSION}

\section{Market Integration And The International Practice Of Accountancy}

One of FEE'S major objectives is the liberalisation of the international practice of accountancy and the removal of barriers which stand in the way of the free movement of accountants, accountancy firms and accountancy services, primarily in Europe, but further a field as well. Achieving this objective requires the free movement of services, services providers, consumers, know-how and payments. In principle, this sounds simple, but in reality, the situation is much more complex. Not just the end product (services) has to circulate freely, but all the related factors of production

\section{Scope of Accountancy Services}

All professions, to a greater or less extent, are complex and broad in scope, but this is especially the case for the accountancy profession. Historically, the range of accountancy services has been demand-driven in response to the requirements of the marketplace and the public interest, rather than supply-constrained by reference to the traditional areas of practice. As demand patterns continue to change, and pressure from clients grows, the diversity of accountancy services becomes greater. Today, in Europe, these service areas include accounting, audit and other assurance services, taxation, legal services, insolvency, consulting, investment administration and advice, and valuation and litigation support. The question confronting the profession is whether our current regulatory structures will allow us to maintain and enhance this service range in a manner which meets the needs of a global economy.

\section{Areas Requiring Regulation}

The main reason why the supply structures of the profession have not been able to internationalise in response to the globalisation of our clients and their requirements is regulation. In the case of accountancy and other professions, regulation acts to prevent the free operation of market forces, and hence impedes the process of inter-nationalisation. However, this is not to say that regulation is bad-far from it. A consensus has always existed, both within professions, professions, that some degree of regulation is not just not just necessary but also 
desirable to protect the quality of services and the interests of those, be they clients or the public, who rely on them. Areas accepted as requiring regulation include technical and performance standards, competence, integrity and enforcement.

However, in discharging their regulatory responsibilities, the competent authorities in different countries have gone about their tasks in different ways, and it is this which causes the problems.

\section{Barriers to Intemational Practice}

Because of differences in regulatory approach, barriers to free factor movement exist, which severely curtail the ability of accountants and accountancy firms to practice internationally. Some impediments apply to all businesses, irrespective of the sector within which they operate, whilst others apply more specifically to the accountancy profession. Examples include the following.

\section{General Impediments}

\section{Restrictions on international payments}

Countries can prohibit or ration different categories of intemational payments, both inward and outward, or oblige the conversion to or from foreign currencies at disadvantageous exchange rates. Different rules may apply to capital transfers, repatriation of profits, payment for current transactions and so forth. As a consequence, the cross-border provision of services, personnel and know-how is discouraged or prohibited, as is investment in a permanent presence or the sharing of costs or profits with a local affiliate.

\section{Restrictions on the mobility of personnel}

Visa, work-permit and immigration provisions may prohibit or restrict the ability to move persons with specific skills to the location where they could be deployed most effectively. This may apply to both short-term and longterm stays, and to management or specialist staff. In many cases, such mobility is necessary to serve clients directly, transfer know-how or manage a foreign permanent presence, so the inability to do so is a severe impediment.

\section{Impediments to technology and information transfer}

As much accountancy firm know-how is proprietary, and is frequently materialised in documentary or software form, firms may be reluctant to transfer such know-how to jurisdictions without adequate copyright and other intellectual property protection provisions. Restrictions on information transfer, which often arise from data protection and personal privacy provisions, may require processing of information to take place locally, even when it could be done more efficiently elsewhere. Some countries even prohibit the removal of audit and other working papers from their national jurisdictions, which constitutes an obligation to maintain a permanent presence, even when cross-border activity may be the preferred means of service delivery. 


\section{"Buy National" public procurement practices}

Many national and sub-national governmental authorities and public-sector organisations purchase goods and services from local providers only. In some cases, local branches, subsidiaries or affiliates of foreign firms are not eligible for public procurement purchases. At a minimum, this excludes crossborder provision of services and requires a local permanent presence, but it may further exclude a foreign provider totally from a significant market, irrespective of the mode of delivery chosen.

\section{Differential taxation treatment and double taxation}

Explicitly and intentionally discriminatory taxation provisions may disadvantage foreign or foreign-associated services providers in favour of local competitors, and the absence of sufficient reliefs may lead to the double teixation in different jurisdictions of the same revenues, profits or interest and royalty pajrments.

\section{Monopolies}

Where certain services are provided by a single monopoly, access to that market is not possible by foreign providers.

\section{Subsidies}

Governments may award selective or fornationals-only subsidies, which place foreign services providers at an insurmountable or substantial disadvantage.

\section{Specific Impediments Nationality requirements.}

Many accountancy services are regulated in different jurisdictions in a $\mathrm{m}$ anner whereby only certain authorised persons may provide them. Where nationality requirements must be met, foreigners are thereby excluded.

\section{Residence and establishment requirements}

Although less restrictive than a nationality requirement, the obligation to be established in or resident of the jurisdiction where the service is provided excludes the possibility of serving a market on a crossborder basis.

\section{Professional certification and entry requirements}

Even in the absence of associated nationality or residence and establishment requirements, the obligation to hold a specific authorisation to provide certain services-although in itself justifiable-can operate in a manner which discriminates, de facto, against foreign services providers who in fact possess all or most of the competence and ability required. Permission to sit the relevant examinations may not be available when desired, it may be subject to unreasonable prior conditions, or inadequate or no credit may be given for the competence and experience evidenced by the possession of foreign academic or professional qualifications.

\section{Scope of practice limitations.}

Because of differences in regulatory approach between countries, accountants or accountancy firms may not be able to provide in other 
jurisdictions the entire range of services they provide in their home country. Non-regulated services in one country may be regulated in another, requiring compliance with additional regulatory burdens. Services provided by accountants in one country may be reserved to other professions in other countries. Certain combinations of services, either in general or in the case of specific clients, may be prohibited in some jurisdictions yet permitted in others. As a result, a uniform service range may often not be offered across several markets, and firms from narrow-scope countries may find themselves at a disadvantage in broad-scope markets and against broad-scope competitors.

\section{Restrictions on advertising, solicitation and fee-setting.}

When seeking to enter new markets, foreign services providers may consider themselves handicapped if they cannot advertise and otherwise attract new clients, or if they are prohibited fi-om competing on the basis of price.

\section{Quantitative restrictions on the provision of services.}

Some countries place limitations on the volume of services which may be provided by professional firms, usually by reference to the number of partners or professional staff in the firm. Arguments of quality control are used to justify such restrictions, but they may unreasonably penalise firms which, by virtue of superior organisation or methodology, may in fact be capable of providing quality services in a higher volume than foreseen by the regulations.

\section{Restrictions on business structures.}

Accountants are frequently constrained as to the business structures through which they provide their services. Unlike other businesses, they may be prohibited fi"om using certain legal forms of firm and, even when permitted to use certain types of legal entities, they may be subject to special restrictions, e.g., number of partners, unlimited liability in certain or all circumstances, ownership, management, control, etc. This can have negative implications with respect to size, management structure, risk management and diversification, the raising of external capital, transferability of ownership, taxation, multidisciplinary practice, the ability to acquire or be acquired by other firms, etc.

\section{Restrictions on international relationships and the use of firm names.}

In some jurisdictions, firms are not permitted to call themselves by the name of the international network with which they are associated. This can prevent the operation of the reputation effect and restricts the firm's marketing capacity. Some countries explicitly prevent relationships between local firms and international networks. In most countries, all or a majority of the ownership, management and control of a firm must be in the hands of nationals or locally qualified professionals, which prevents foreign firms from having branches or subsidiaries in that country. 
Differences in Accounting, Auditing, and Other Standards.

These differences impede the transfer of personnel and know-how, and lead to services "produced" in one jurisdiction not being accepted for "consumption" in another, e.g., financial statements and audit reports for regulatory purposes.

Certain of these barriers arise from discriminatory laws and regulations, but even nondiscriminatory provisions may give rise to significant impediments. This reflects the fundamental difference between trade in goods and trade in services. In the case of the former, the main barriers to trade have traditionally been at the border, in the form of tariffs, quantitative restrictions and the like, whereas in the case of the latter, the barriers are not so much at the border, but instead are imbedded in the distinctive, and often very different, features of domestic regulatory regimes governing the provision of the services in question.

As a result, far firom being a truly international profession, accountants find themselves faced with the severe risk of being marginalised to the role of local players in an increasingly global economy.

\section{EVOLUTION OF EU REGULATION}

Having described the problems, it is now appropriate to turn to possible solutions, and to begin with Europe. I will focus in particular on issues related to standards and practice rights. Since the outset, what is now known as the European Union (EU) has had as its objective the firee movement of goods, services, capital and people, which includes, by definition, the firee movement of accountants, accountancy firms and accountancy services, together with the related consumers and payments. Different initiatives have been launched to overcome regulatory divergence in order to achieve market integration, and these are of relevance elsewhere in the world. However, it is important to understand that policy approaches have evolved and developed over time, as lessons have been learned from failures and mistakes, so in deciding which elements (particularly the earlier ones) of the EU experience to replicate, care should be taken by others.

For the EU, market integration has always been an end in itself, so that internationalization is not an optional choice for Europeans-t is an imperative. The only room for debate has been on how best to achieve it. This reflects the origins of the Union, which is based on the profound desire to link our countries so closely that never again will they go to war with each other, as happened so catastrophically twice in the first half of this century.

In tackling the barriers created by regulatory diversity there has been a recognition of the need for some degree of regulation to correct market failures, but also a wish to avoid the problems of regulatory failure. It is accepted that regulation has costs as well as benefits. The objective has been to maximise the benefits and minimise the costs on a pan-European, economy-wide basis. This has necessitated an integrated EU approach to defining and protecting the public interest, and to striking an 
appropriate balance between the different facets of the public interest, again on a pan-European, economy-wide basis.

\section{Regulatory Cooperation}

The first phase of EU integration began 40 years ago with the signing of the Treaty of Rome (in 1957), which had as its aim the creation of a Common Market. The basic approach adopted was one of first legislating to remove regulatory differences and then permitting the free flow of goods, services, capital and people on a uniform, level playingfield. Moves towards integration were therefore characterised by harmonisation and regiilation, based on host-country control. Each Member State retained substantial regulatory sovereignty,since all decisions at European level were on the basis of unanimity, so this period can be characterised as one of regulatory cooperation. Free movement was deferred until the relevant regulations had been harmonised, but no changes could be made until all Member States were in agreement. In any one Member State, only national and agreed European regulations applied, the Common Market operated only in the areas where agreement had been reached, and the different regulations of other Member States were of no impact or application.

Harmonisation was the basis for the first legislative measures directly to affect accountancy. As part of the series of company law directives (EU legislation which must be incorporated in national law), the late 1970s and early 1980s saw the adoption of requirements which sought to reduce differences in both financial reporting (Fourth and Seventh Directives) (European Communities 1978,1983) and the education, training and licensing of auditors (Eighth Directive) (European Communities 1984). However, because of incomplete coverage and the acceptance of a wide range of alternative treatments, or the fixing only of minimum levels which individual Member States were fi-ee to exceed, substantial divergences remained. For this reason, neither financial statements nor professional qualifications fi'om one Member State were automatically accepted elsewhere.

As far as the professions were concerned, the free movement benefits of the Common Market were confined to those groups (architects and health care professionals) where education and training requirements could be harmonised to a significant extent, because of a high degree of functional similarity across borders. For those professions more susceptible to continuing national differences in areas such as the law (e.g., accountants and lawyers), the necessary degree of harmonisation was not possible to achieve, so the Common Market simply did not become a reality.

\section{Regulatory Competition}

The second phase of EU integration was marked by the entry into force 30 years later of the Single European Act in 1987, although certain of its features had effect earlier. Recognising the impossibility of completing the Common Market under the constraints of regulatory cooperation, a new approach was 
followed. Instead of waiting until regulatory differences were removed before allowing the free movement of goods, services, capital and people, barriers were lifted even while regulatory divergence persisted. This liberalisation was founded on the principle of mutual recognition, whereby domestic authorities had to recognize and accept the requirements of other Member States, even if these had not been harmonised. Simultaneous unilateral deregulation in many Member States reinforced the effect. Regulatory control passed firom the host Member State to the home Member State, thereby replacing regulatory cooperation with regulatory competition, as the requirements of all Member States gained application and recognition in each. Where this had not already been achieved during the previous phase of regulatory cooperation, a safety net of harmonized minimum requirements was put in place at European level, but on the basis of majority voting rather than unanimity, so that individual Member States lost their veto right.

This second phase constituted a significant step forward, since market integration was given precedence over regulatory sovereignty. Regulatory divergence could be overcome without having to wait for regulators to agree. Regulators were forced to adapt to the imperative of market integration, rather than vice versa. This dilution of the monopoly of regulation meant that the regulation of markets was complemented by a market in regulation, as economic agents could choose the regulatory regime of their liking. In a sense, this was simply a recognition of reality. Given the absence of exchange controls, domestic investors were already fi-ee to buy shares on foreign markets, and increasing numbers of transactions were taking place off traditional regulated markets (e.g., as the Eurobond market).

\section{Mutual Recognition of Financial Statements}

With respect to financial reporting, the principle of mutual recognition found its most concrete expression in the requirement that financial statements from any Member State must be accepted for regulatory purposes in all other Member States without any restatement or reconciliation, despite the significant differences in national practice which remain. The safety net provided by the accounting directives was considered sufficient to protect the public interest. A French company, therefore, listed on the Frankfurt Stock Exchange can simply file its French accounts, and is under no obligation to indicate in what respect the financial statements would be different under German requirements. This liberal approach can be contrasted with the less hospitable regime in certain major nonEuropean jurisdictions.

\section{Liberalisation of Accountancy Practice}

As regards the practice of accountancy, at least partial implementation of the new approach came about by means of the directive on a general system for the recognition of higher education diplomas (the "mutual recognition directive") (European Communities 
directive applies to regulated professions which require at least three years' university-level education (or equivalent) plus appropriate jobbased training. It supplements a series of earlier sectoral mutual recognition directives, covering architects, veterinarians and certain health care professions.

The general system directive permits an accountant carrying on regulated activities in one Member State, and using a profession title to do so, to move to another Member State and have the right to the equivalent title in that country, thus obtaining a licence to carry out the same activities. It should be noted that access to the new title is not automatic, but is subject to compensation procedures necessary to protect the public interest by making up for major deficiencies between the home and host country qualifications. In the case of the accountancy profession. Member States have opted for test in local law and tax. Again, the safety net provided by the Eighth Directive (European Communities 1984) was considered to give sufficient protection.

The directive is a step in the direction of a single market in accountancy services, but barriers and problems still remain in some particularly important areas.^ ${ }^{\wedge}$ It applies only to individuals and addresses only establishmentbased provision of services. It does not cover firms (which are the major providers of accountancy services in most countries) or the crossborder provision of services into a country where the provider (either firm or individual) is not established.

Ethical supervision of migrant accountants is on a host-country basis, but the migrant continues to be bound as well by his home country's ethical rules and, in either case, by the more onerous of the two. This can have unusual implications.

Additional restrictions can prevent the migrant accountant from providing in the host Member State the full range or combination of services which he provided in his home Member State, and for which his education, training and experience give him the necessary competence. These problems arise fi-om continuing differences between countries as regards the types of services regulated, permitted scope of practice, ethical requirements and so forth. Restrictions on allowed legal forms for the exercise of the profession and on competitive behaviour can limit the choice of vehicles for the provision of services, affect exposure to commercial risk and constrain the possibilities for attracting new clients.

The relatively limited use made so far of the rights granted by the directive (less than 100 successful candidates to date) demonstrates that it does not address the main concerns of the accountancy profession and that it will make only a minor contribution to the creation of a single market in accountancy services. The directive does not create a single market, but rather emphasizes-through the continued application of host- rather than home-Member State control-the continuing existence of 15 separate national markets. As such, and if the objective of a true single market is to be achieved, the new regime can only be regarded 
as a provisional one which, sooner or later, will have to change.

Specifically, FEE has called for the following additional freedoms, and is now working with the European Commission to develop proposals for a sectoral liberalisation directive tailored to the needs of the accountancy profession.

\section{Freedom for individual accountants to provide services on a cross-border basis}

This would require the removal of the permanent establishment obligations currently in force in many Member States.

\section{Freedom for accountancy firms to provide services on a cross-border basis}

This, too, would require the removal of establishment obligations. Also necessary would be the mutual recognition of legal forms used to exercise the profession, and the relaxation of local ownership requirements such that foreign-owned firms would be accepted to practice locally.

\section{Freedom for foreign accountancy firms to establish local branches and subsidiaries}

If establishment requirements are maintained, or if firms simply prefer to be present in a market by way of a permanent presence rather than cross-border, allowing foreign firms to establish local branches and subsidiaries would permit greater liberalisation. It would also be necessary to relax local ownership requirements so that foreign direct investment (FDI) in professional services would become a possibility for the first time.

Freedom for accountancy firms and individual accountants from several Member States jointly to create and own a single practicing firm

Strange though it may seem, 40 years after the signing of the Treaty of Rome, local ownership requirements in all Member States make it impossible to create single, combined international firms in which the professionals of no single country hold a majority stake. It is for this reason that complex and expensive contractual cooperation networks have to be put in place if firms and individuals wish to work togetiher multi-nationally to service clients with activities in more than one country. This must change.

\section{Regulatory Contracting-Out}

The third phase of EU integration, going beyond regulatory competition, is that signaled by the Treaty of Maastricht, which entered into force in 1993 and which has as its objective the creation of a European Union. By emphasising the pre-existing concept of subsidiarity, new weight was attached to the process of regulatory decentralisation, so that decisions best made at local level were not preempted by EU legislation. However, it would be wrong to regard this as strengthening the regulatory sovereignty of Member States. Firstly, subsidiarity can be used as a justification for delegating decision making to sub-national or even non-governmental bodies, such as the professions, which has led some observers to 
consider it as leading to a process of regulatory contracting-out. If, as in the case in the accountancy profession, professional bodies can coordinate their standard-setting activities across borders, this can achieve the removal of many impediments to international practice without any need for further governmental or legislative intervention. Secondly, the accompanying concept of proportionality means that Member States must have regard for the needs of the Single Market when regulating at national level. Member States remain free to choose whether to regulate certain activities and services in the public interest, but the manner in which they do so-even if non-discriminatorycan be held up to external scrutiny at EU level if it has any distorting effect on the operation of the Single Market. The interests of the Single Market take precedence over national interests.

This move towards a new phase of regulatory integration was accompanied by confirmation of the European Union's determination to be an open and outwardlooking player in the global economy. Accusations that the EU would become a "Fortress Europe" were always ill-founded, but the more the separate national economies of the different Member States came together, the more it was realised that any form of protectionism would be self-defeating. The EU Single Market is the world's largest economic bloc. It accounts for more trade and investment fiows than any other unit, and such external transactions form a much higher percentage of its GDP than is the case for either Japan or the United States, for example. Far from turning in on itself, the EU recognizes its special responsibility for the continuing good health of the global economy and has, in fact, increased its openness to others. Nowhere has this been made clearer than in its willingness to expand to bring in new members from Central and Eastern Europe, despite their quite different levels of development, but it is also evident in a strengthened commitment to worldwide institutions and rules, such as the World Trade Organisation. All that is expected in return is a similar openness by our partners.

Bearing in mind this global orientation, and taking the post-Maastricht approach to its logical conclusion, in November 1995 the European Commission announced its new strategy for accounting harmonisation. The strategy has since received the full support of the national governments of the 15 Member States. Rather than seeking new regulatory solutions at European level, the Commission encouraged Member States to allow their companies, at least in consolidated financial statements, to use International Accounting Standards (IASs), both to improve international comparability and to facilitate access by European companies to non-EU financial and capital markets. As a result, proposals are now under consideration in Belgium, France and Germany which would allow certain companies to prepare their consolidated accounts using IASs rather than national accounting requirements. Noting that there are currently no significant confiicts between the accounting directives and existing IASs, the Commission has indicated its willingness to propose 
amendments to the directives should any such confiicts arise with future international standards. Naturally, the new strategy calls for an enhanced European input to the work of the International Accounting Standards Committee (IASC), but what is of note is the fact that the EU and its Member States are prepared to support the standards issued by a worldwide private organization over which they exercise no control, in order to advance market integration, not just in Europe but internationally. Similar support is expected to follow for the International Standards on Auditing (ISAs) issued by the International Auditing Practices Committee (IAPC) of the International Federation of Accountants (IFAC), once a detailed study on the relevance of ISAs to the EU, currently being undertaken by FEE for the European Commission, is completed.

\section{Economic and Monetary Union}

No overview of European integration would be complete without reference to the introduction, on January 1, 1999, of the Euro, the single ctirrency for the single market. Although the dehate on which of the Member States will participate from the outset will not be resolved until May 1998, the consequences are already clear. The pooling of sovereignty, which is at the heart of European integration, will be strengthened, by the conduct of a single monetary policy. The single market will be enhanced, not just through the greater price and cost transparency which the use of a common currency will bring, but through the lowering of the costs of trade and investment which will follow from the elimination of exchange rate risk. In particular, this will lead to greater integration of Europe's capital and financial markets, a process in which financial reporting and the accountancy profession will have a key role to play. The mechanisms already put in place to overcome regulatory divergence in the accountancy field will accelerate market integration, while greater integration will push forward regulatory convergence. Furthermore, the use of international standards as the basis for this convergence will ensure that the process is compatible with globalisation at a worldwide level, and not a threat to it.

\section{THE POSITION OF THE UNITED STATES}

Given the size and market structure of the United States, as well as the current strength of its economy, there is a temptation to consider the EU model just described as being of academic interest, but of no immediate relevance. Why should the system of accountancy regulation in the U.S. be subject to the same pressures for change as elsewhere? The answers to this question are clear. Firstly, globalisation is a worldwide, not a European, phenomenon. Secondly, the process of regulatory change has already begun. Its impact on financial reporting and the practice of accountancy may not yet be very noticeable, but a number of examples can be cited.

\section{World Trade Organisation-General Agreement on Trade in Services}

The United States was one of the principal 
signatories to the Marrakesh Agreement which. in 1994, brought to a successful conclusion the Uruguay Round of trade negotiations. Covering over 100 countries (including the EU), the agreement established the World Trade Organisation (WTO) and made operative the General Agreement on Trade in Services (GATS). On a worldwide basis, GATS seeks to break down regulatory barriers to trade and investment in services, including accountancy, and sets out a series of rules to discipline regulatory intervention in the marketplace. The broad objective of these rules is two-fold: to ensure that foreigners enjoy the same privileges as their domestic counterparts with respect to regulation, and to remove discriminatory obstacles to market access by foreigners.

Article VI of GATS, on domestic regulation, contains three important features:

1. Governments agree to apply regulations affecting service industries and professions in a reasonable, objective and impartial manner so that they do not act as barriers to trade.

2. Qualification requirements and procedures, technical standards and licensing requirements should not constitute unnecessary barriers to trade in services. Further disciplines or rules shall be developed on a sector-by-sector basis to make sure such measures are based on objective and transparent criteria, are not more burdensome than necessary to ensure the quality of the service, and, in the case of licensing requirements, do not in themselves serve as restrictions on the supply of the service. International standards should be taken into account in determining compliance with these principles.

3. Countries must have adequate procedures in place to verify the qualifications of professionals from other countries seeking the right to practise within their jurisdictions.

The task of applying these general principles to financial reporting and the practice of accountancy was assigned to the WTO Working Party on Professional Services (WPPS), where the United States is an active and constructive participant. Although responsible for all the professions, the WPPS was mandated to deal with accountancy as a matter of priority, operating on a three-point agenda:

1. Develop detailed disciplines to ensure that the requirements, procedures and standards referred to in Article VI do not constitute unnecessary barriers to trade.

2. Encourage the use of international standards through cooperation with the relevant intemationai governmental and nongovernmental organisations.

3. Facilitate the cross-border recognition of qualifications through the development of guidelines for recognition agreements.

The WPPS has been given a deadline of the end of 1997 for the substantial completion of its work on accountancy, and much remains to be done in relation to the disciplines on 
domestic regulation. Significant progress has been made in the other two areas, however. Firstly, guidelines on recognition agreements were finalised in May 1997, but many countries had already responded to the liberalizing intent of GATS once the Marrakesh agreement had been signed over three years ago. In the United States, for example, the International Qualifications Appraisal Board was established, as part of a process which makes it easier for certain foreign accountants to acquire the CPA designation. Secondly, at their meeting in Singapore December 1996, the world's trade ministers, including the United States Trade Representative, expressed their support for the work being undertaken by the International Accounting Standards Committee and the International Federation of Accountants, in cooperation with the Intemationai Organisation of Securities Commissions, to develop international standards relevant to accountancy.

\section{Organisation for Economic Cooperation and Development-Regulatory Reform Project}

The Organisation for Economic Cooperation and Development (OECD) is the body which brings together the governments of the 29 most developed countries, including the United States and the European Union. With the support ofall its members, and under the leadership of its Deputy Secretary-General, Ms. Joanna Shelton of the U.S., in June 1997 the OECD (1987) published a major report on regulatory reform which sets out a number of recommendations for adapting systems of national regulation to enable countries to compete better in a global economy. Good regulation is seen as that which facilitates international competition, trade and investment, and countries are encouraged to reform their regulatory and standard-setting processes to achieve this aim. When developing new regulations, countries are encouraged to take into account the interests of all affected parties, whether domestic or foreign. With this in mind, the report calls for the development and use of internationally harmonised standards as a basis for domestic regulations, as well as for collaboration with other countries to review and improve intemationai standards to ensure they continue to achieve their intended policy goals efficiently and effectively.

\section{International Organisation of Securities Commissions-Cooperation with IASC and IFAC}

In recognition of the globalisation of capital and financial markets, the U.S. Securities and Exchange Commission was one of the founding members, in 1986, of the International Organisation of Securities Commissions (IOSCO), which groups together the world's major regulators. In 1987, IOSCO decided that regulatory authorities should aim to promote the use of common accounting standards, so that the SEC, for example, would no longer need to require the reconciliation of the financial statements of foreign registrants to U.S. GAAP. This was recognised as being an ambitious objective, but significant progress has been made towards achieving it.

In July 1995, agreement was announced between IOSCO and IASC on a programme of 
work by IASC to be completed by Autumn 1999 which, if successfully concluded, would result in a comprehensive core set of standards which IOSCO could endorse and which its member organisations could accept for crossborder offerings and other foreign listings. Since then, the target date for completion has been moved forward by the IASC to Spring 1998. It is clear that no final decision on IOSCO endorsement will be made until the completed work has been evaluated. Several eminent commentators have cast doubt on whether the decision will be favourable. Much, if not all, depends on the view taken by the SEC, which has made clear its three conditions for acceptance:

1. IASC standards should include a core set of accounting pronouncements that constitute a comprehensive, generally accepted basis of accounting.

2. IASC standards should be of high quality; they must result in comparability and transparency, and they must provide for full disclosure.

3. IASC standards should be rigorously interpreted and applied.

The European Commission's new accounting strategy of 1995 gives a fair reflection of Europe's view of IASC's performance against the first two criteria, and the subsequent decision by IASC to establish a Standing Interpretations Committee should provide reassurance with respect to the third. If IOSCO and SEC support were not to be forthcoming in accordance with the timetable foreseen, this would not be taken well in Europe. For me, though, the key decision has already been made: by being party to the IOSCO-IASC agreement in the first place, the SEC has recognised the need to adapt the U.S. regulatory system to the demands of the global economy. Support for a set of international standards can only be a question of "when," not "if" Given this, it is surely in the interests of all concerned that support be signaled as soon as possible. To the extent that certain issues remain outstanding when the Spring 1998 target arrives, further progress is best achieved by working on the inside, seeking improvement, rather than by remaining outside, looking for fault. Because of the need for constant improvement, not even the best set of national standards can be considered perfect, and it seems unreasonable to require more of a worldwide body than of its domestic counterparts.

Successful endorsement of IASC's International Accounting Standards should then pave the way for similar acceptance of IAPC's International Standards on Auditing, further increasing the reliance placed on financial statements cross-border.

In fact, U.S. regulators and standard setters have already been closely involved in various international harmonisation initiatives. Observers firom both the SEC and FASB attend meetings of the IASC Board and participate actively in discussions. The FASB, together with the IASC and FEE, was instrumental in organising the first meeting of accounting standard setters from throughout the world, 
which took place in Brussels in 1991. The FASB's 1994 decision on earnings per share, where it entered into a joint project with the IASC, was made on the basis that it would change U.S. GAAP. Much remains to be done, but a start has been made.

\section{FUTURE POLICY TRENDS}

As explained, removing the barriers to the international practice of accountancy requires a strategy for overcoming regulatory divergence between countries. Based on the evolution of policy approaches applied in the EU and the logic which underlies GATS, OECD's proposals for regulatory reform, and IOSCO's cooperation with IASC and IFAC, it is clear that future developments will be based on a complex mix of regulatory cooperation, regulatory competition and regulatory contracting-out, and the imposition of external disciplines and constraints on the freedom of action of national regulators. This requires a switch in regulatory focus firom the national to the global if the valid interests of those who rely on financial reports and the services of the accountancy profession are to be protected in the new liberalised environment.

\section{Challenges for Regulators}

Nobody likes being forced to change, so protests can be expected as the necessary shift in emphasis begins to take effect. In assessing the validity of any protestations made, however, the overriding criterion must be whether what is proposed or defended is in the public interest.

It is precisely the changing relationship between geography and the public interest in the new global economy which will be the basis of most of the issues to be confironted during the transition period which lies ahead. At a time when most trade, investment and other commercial activities took place within the fiontiers of a single country, it was justifiable to define and protect the public interest in a geographical sense, i.e., as being bounded by the same frontiers as defined the borders of the country in question. The characteristics of the public interest could be considered to be consistent within those fi-ontiers, no regard needed to be paid to the interests of those elsewhere, and a system of national regulation promulgated by national regulators enjoying complete sovereignty was appropriate.

Since then, the world has moved on. Countries' major companies may have operations and shareholders throughout the world. Local employees may depend on the fortunes of a foreign parent-company for their future prospects. Goods and services are provided to customers not down the road, but on the other side of the globe. The assets backing up domestic pension funds can be spread throughout the world. In this situation, the public interest can no longer be defined in purely national terms, nor can it be assumed that all consumers of services have the same interests. A sophisticated fund manager in London has little in common as regards financial reporting with a neighbour holding $£ 250$ of shares bought in some privatisation, but she or he probably will share many similar interests and concerns with an institutional 
investor in New York. We have moved fi"om a situation of domestic consistency and differences between countries to one of domestic divergence and international similarities. The fi"ontiers of the public interest (or perhaps, more accurately, the public interests) are no longer vertical between countries, but horizontal across borders. Global mechanisms are needed to protect the global public interest, to complement national regulations dealing with issues of purely domestic concern, and to provide a safety net of common minimum standards when the mutual recognition of foreign standards is agreed to not be appropriate. It has always been difficult enough to answer the question: What is the public interest? Now we must also ask: Where is the public interest? This is a trend which can only become more acute as increasing numbers of transactions are conducted on the Internet.

Hence, a degree of scepticism is required when considering the appeals of those who would call for the preservation of the regulatory status quo to protect the public interest. Is the principal aim of national regulators in a global economy to protect the public interest or to protect regulatory turf?

That the new world economic order is a threat to national regulators leads one to consider whether Francis Fukuyama got it wrong. Instead of focusing on the new world political order and "The End of History and the Last Man," should he not have written "The End of Geography and the Last Regulator?" The answer, quite simply and emphatically, is "No."

The safeguarding of the interests of those who rely on professional services such as accountancy requires a system of robust and effective regulation. What is at issue is not the existence of regulation, but its appropriateness. At the same time as providing protection it must be appropriate to, and facilitating of, internationalisation. It must take account of the imperative of breaking down barriers between national markets. Only if national regulators recognise this and act accordingly, building the trust needed to accept each others' standards or working together with IASC and IFAC to develop common standards, will their future be assured.

Some regulators may consider that the best response lies in making their national standards the global standards, perhaps with a few cosmetic changes to their standard-setting process to give a veneer of greater international acceptability. This is not an option. To make a sporting analogy, the U.S. national baseball championship cannot be considered a global event simply by calling it the "World Series," admitting a few teams firom north of the border, and even allowing the Blue Jays to win from time to time. Global standards are not a substitute for national standards, but a complement to them. Strong national standard setters will remain an essential element in any system to set international standards, but the protection of the global public interest requires a global perspective. National regulation is not doomed to disappear, but national regulators are compelled to cooperate. 


\section{Challenges for the Profession}

Adapting to the new environment of a

liberalised global marketplace will not necessarily be easy for professional accountancy bodies. In order to contribute to the development of a framework for appropriate regulation, many sensitive issues will have to he confronted, those that go to the heart of how accountants and accountancy firms do business, and how they position themselves to compete in the marketplace. The increased reliance placed, through the process of regulatory contractingout, on the international standards developed by IASC and IFAC is a tribute to the profession's vision in creating these bodies in 1973 and 1977, respectively. But contracting-out is not self-regulation. To enhance the acceptance of international standards, the profession must increase the involvement of regulators, preparers and users. Education, training and examination requirements need to be adapted. National professional bodies must redefine their roles and relevance in an international context.

For firms and individual accountants, liberalisation will lead to greater competition both domestically and internationally. New firm and management structures must be devised to guide global practices. Diversity of cultures must be coped with, and methodologies, procedures and skill sets adapted. Personnel development becomes both more important and more complex. New links have to be negotiated and agreed upon between global firms, on the one hand, and national professional bodies and regulators on the other.

\section{Opportunities for the Profession}

Outweighing the challenges, though, are the opportunities provided by liberalisation. For the first time, the accountancy profession, accountancy firms and individual accountants will be able to respond appropriately to the globalisation of the economy, as nationally sourced restrictions and constraints are removed. Greater freedom will be provided to respond to the true needs of clients and the public interest. The scope of firms and individuals will expand, not just geographically but also in terms of the range of services provided. There will be a greater choice of business structures for the exercise of the profession, accompanied by more freedom and flexibility to deploy people, know-how and capital where they are most needed and most profitable. A renewed emphasis on regulatory contracting-out will give practitioners a more important role in the governance of their own profession.

Much remains to be done to make these prospects a reality. The objective of this article was to identify trends, not to state where we had already got to. In many cases, the greatest opportunities are those of greater choice, and each professional is free to choose how she or he wishes to respond. For my part, I remain confident of my profession's ability to rise to the challenge ahead. 


\section{Challenges for the Profession}

Adapting to the new environment of a

liberalised global marketplace will not necessarily be easy for professional accountancy bodies. In order to contribute to the development of a framework for appropriate regulation, many sensitive issues will have to he confronted, those that go to the heart of how accountants and accountancy firms do business, and how they position themselves to compete in the marketplace. The increased reliance placed, through the process of regulatory contractingout, on the international standards developed by IASC and IFAC is a tribute to the profession's vision in creating these bodies in 1973 and 1977, respectively. But contracting-out is not self-regulation. To enhance the acceptance of international standards, the profession must increase the involvement of regulators, preparers and users. Education, training and examination requirements need to be adapted. National professional bodies must redefine their roles and relevance in an international context.

For firms and individual accountants, liberalisation will lead to greater competition both domestically and internationally. New firm and management structures must be devised to guide global practices. Diversity of cultures must be coped with, and methodologies, procedures and skill sets adapted. Personnel development becomes both more important and more complex. New links have to be negotiated and agreed upon between global firms, on the one hand, and national professional bodies and regulators on the other.

\section{Opportunities for the Profession}

Outweighing the challenges, though, are the opportunities provided by liberalisation. For the first time, the accountancy profession, accountancy firms and individual accountants will be able to respond appropriately to the globalisation of the economy, as nationally sourced restrictions and constraints are removed. Greater freedom will be provided to respond to the true needs of clients and the public interest. The scope of firms and individuals will expand, not just geographically but also in terms of the range of services provided. There will be a greater choice of business structures for the exercise of the profession, accompanied by more freedom and flexibility to deploy people, know-how and capital where they are most needed and most profitable. A renewed emphasis on regulatory contracting-out will give practitioners a more important role in the governance of their own profession.

Much remains to be done to make these prospects a reality. The objective of this article was to identify trends, not to state where we had already got to. In many cases, the greatest opportunities are those of greater choice, and each professional is free to choose how she or he wishes to respond. For my part, I remain confident of my profession's ability to rise to the challenge ahead. 


\section{REFERENCES}

Cairns, D. 1997. The future shape of harmonisation: A reply. The European Accounting Review 6(2):305-348.

European Commission. 1995. Accounting Harmonisation: A New Strategy vis-avis International

Harmonisation-COM (95) 508. Brussels, BELG: European Commission.

European Communities. 1978. Fourth Council Directive 78/660/EEC of 25 July 1978 based on Article 54(3) (g) of the Treaty on the annual accounts of certain $\mathrm{t} 5^{\wedge} \mathrm{es}$ of companies.

Official Journal of the European Comm, unities: O. J. L222/11.. 1983. Seventh Council Directive 83/349/EEC of 13 June 1983 based on Article 54 (3) (g) of the Treaty on consolidated accounts.

Official Journal of the European Communities:

O. J. L193/1. Accounting Horizons/ December 1997

1984. Eighth Council Directive 84/253/EEC of 10 April 1984 on the approval of persons responsible for carrying out the statutory audits of accounting documents.

Official Journal of the European Communities: O. J. L126/20.

1989. Council Directive 89/48/EEC of 21 December 1988 on a general system for the recognition of higher-education diplomas awarded on completion of professional education and training of at least three years' duration.

Official Joumal of the European Communities: O. J.L19/16.

Federation des Experts Comptables Europ6ens (FEE). 1996. The Role, Position and Liability of the Statutory Auditor in the European Union. Brussels: FEE.
Organisation for Economic Cooperation and Development (OECD). 1997. OECD Report on Resulatorv Reform. Paris: OECD. $s j$

TroUiet, C. 1994. L'Exercice de la Profession Comptable dans la CEE. Paris: Editions Comptables Malesherbes.

Worid Trade Organisation. 1994. The Results of the Uruguay Round of Multilateral Trade Negotiations-The Legal Texts. Geneva, SWITZ: WTO. 